\title{
CELL CYCLE ANALYSIS AND INTERSPECIES NUCLEAR TRANSFER OF CAT CELLS TREATED WITH CHEMICAL INHIBITORS
}

\author{
Manita WitTAYARAT ${ }^{1,2}$, Akira FuJiWARA ${ }^{1}$, Kaywalee CHATdARONG ${ }^{2}$, \\ Mongkol TeCHAKUMPHU ${ }^{2}$, Yoko SATO ${ }^{1}$, Fuminori TANIHARA ${ }^{1}$, Yasuhiro Morita ${ }^{1}$, \\ Masayasu TANIGUCHI ${ }^{1}$ and Takeshige OTOI ${ }^{*}$ \\ ${ }^{1}$ The United Graduate School of Veterinary Science, Yamaguchi University, \\ Yamaguchi 753-8515, Japan; ${ }^{2}$ Faculty of Veterinary Sciences, \\ Chulalongkorn University, Bangkok 10330, Thailand
}

(Received 26 September 2012; accepted 2 April 2013)

This study investigated the effect of chemical inhibitors on the cell-cycle synchronisation in cat fibroblast cells and evaluated the development of interspecies embryos reconstructed from cat donor cells and enucleated bovine oocytes. Cat fibroblast cells were treated with $15 \mu \mathrm{g} / \mathrm{mL}$ roscovitine or $0.05 \mu \mathrm{g} / \mathrm{mL}$ demecolcine prior to cell cycle analysis and nuclear transfer. The percentage of cat fibroblast cells arrested at the G0/G1 phase in the roscovitine group was similar to that in the control group without any treatment. The percentage of cells arrested at the $\mathrm{G} 2 / \mathrm{M}$ phase was significantly higher in the demecolcine group than in the control group. The fusion rate of interspecies couplets was significantly greater in the roscovitine group than in the control group. Most embryos stopped the development at the 2- or 4-cell stage, and none developed into blastocysts. Chemical inhibitor-induced donor cell cycle synchronisation did not overcome developmental arrest in interspecies cloned embryos.

Key words: Bovine oocyte, cell cycle synchronisation, demecolcine, feline, roscovitine

Interspecies somatic cell nuclear transfer (iSCNT) is an alternative way to explore species for which oocytes and recipients are limited; these species include endangered or exotic species (Karja et al., 2006). It has been shown that bovine, sheep and rabbit oocyte cytoplasm supports in vitro development of embryos produced by interspecies nuclear transfer of somatic cells from various unrelated mammalian species, although no pregnancy has lasted to full term after the transfer of iSCNT embryos to surrogate animals (Dominko et al., 1999; White et al., 1999; Chen et al., 2002; Murakami et al., 2005). Moreover, the ability of iSCNT embryos to develop into blastocysts decreases as the taxonomic distance between the donor and recipient species increases (Beyhan et al., 2007).

*Corresponding author; E-mail: otoi@yamaguchi-u.ac.jp; Phone/Fax: 0081 (83) 933-5904 
This may be directly related to insufficient reprogramming of the donor cell nuclei after transplantation into enucleated oocytes from different species.

The success of somatic cell nuclear transfer (SCNT) critically depends on the cell-cycle phases of both the donor cell and the recipient cytoplast (Jiang et al., 2005). Use of donor cells in the G0/G1 phase provided better results in the development of a cloned embryo when a metaphase II (MII) oocyte with a high level of maturation-promoting factor (MPF) was used as recipient ooplasm (Campbell et al., 1996). On the other hand, some studies showed that cloned embryos also had developmental capacity after the transfer of somatic cells in the G2/M phase into enucleated MII oocytes (Korfiatis et al., 2001; Zhou et al., 2001). Roscovitine, a cyclin-dependent kinase inhibitor, is commonly used to arrest cells in the G0/G1 phase (Gibbons et al., 2002), while demecolcine, a microtubule inhibitor, can induce cells to enter the G2/M phase ( $\mathrm{Li}$ et al., 2005a). Therefore, the present study was conducted to investigate the effect of chemical inhibitors (roscovitine and demecolcine) on the cell-cycle synchronisation of cat somatic cells and to evaluate the developmental capacity of interspecies cat embryos reconstructed using bovine ooplasm and somatic cells treated with the inhibitors.

\section{Materials and methods}

\section{Preparation of somatic cells and treatment of cell-cycle inhibitors}

Cat fibroblast cells were obtained from shredding of cat ovaries from local veterinary clinics following routine ovariohysterectomy. The owners' consent to using these organs had been acquired by the veterinarian at every clinic. The cells were cultured in plastic 35-mm Petri dishes (Falcon 3001, BD, Franklin Lakes, NJ, USA) containing Dulbecco's modified Eagle's medium (DMEM; Invitrogen, Carlsbad, CA, USA) supplemented with $20 \%$ (v/v) fetal bovine serum (FBS; Invitrogen) and $50 \mu \mathrm{g} / \mathrm{mL}$ gentamicin (Sigma-Aldrich, St. Louis, MO, USA) at $37{ }^{\circ} \mathrm{C}$ in a humidified incubator containing $5 \% \mathrm{CO}_{2}$. Once the cells reached complete confluence, they were trypsinised and frozen for storage in liquid nitrogen. Cells in the second to fifth passages were utilised and cultured in plastic 35-mm Petri dishes for 5-6 days until they reached approximately $80 \%$ confluence. The cells were washed with culture medium consisting of DMEM supplemented with $10 \%$ FBS and $50 \mu \mathrm{g} / \mathrm{mL}$ gentamicin and then incubated for $24 \mathrm{~h}$ in culture medium with or without cell-cycle inhibitor $(15 \mu \mathrm{g} / \mathrm{mL}$ roscovitine [Sigma-Aldrich] or $0.05 \mu \mathrm{g} / \mathrm{mL}$ demecolcine [Sigma-Aldrich]). Cat cells without any treatment served as non-treated controls and homogeneous control (cat NT). As a homogeneous control for bovine NT, bovine cumulus cells were obtained from cumulus-oocyte complexes (COCs) by vortexing and then cultured in the culture medium at $37^{\circ} \mathrm{C}$ in a humidified atmosphere containing $5 \% \mathrm{CO}_{2}$ for $5-6$ days. 


\section{Analysis of cell-cycle and apoptosis}

To analyse the cell-cycle stages of cat fibroblast cells, the cells were disaggregated using $0.25 \%$ trypsin-EDTA (Sigma-Aldrich) prior to fixation. The disaggregated cells (approximately $1 \times 10^{6}$ cells $/ \mathrm{mL}$ ) were washed in PBS (Invitrogen) and then fixed in $75 \%$ ethanol. The fixed cells were stored at $-30{ }^{\circ} \mathrm{C}$ until use. The fixed cells were resuspended in phosphate buffered saline (PBS; Invitrogen) supplemented with $2 \mathrm{mg} / \mathrm{mL}$ RNase (Invitrogen) and incubated at $37^{\circ} \mathrm{C}$ for $30 \mathrm{~min}$. After incubation, the cells were stained using $0.05 \mathrm{mg} / \mathrm{mL}$ of propidium iodide (PI; Sigma-Aldrich) solution and incubated at room temperature for $20 \mathrm{~min}$. The cells were filtered through a $100-\mu \mathrm{M}$ nylon mesh (Becton Dickinson, San Jose, CA, USA) for flow cytometric analysis at an excitation wavelength of $488 \mathrm{~nm}$ and an emission wavelength of $610 \mathrm{~nm}$. The percentage of cells existing within the various cell-cycle phases was calculated by gating on $\mathrm{G} 0 / \mathrm{G} 1$, $\mathrm{S}$ and $\mathrm{G} 2 / \mathrm{M}$ cell populations.

For analysis of cell apoptosis and necrosis, the Annexin V-FLUOS Staining Kit (Roche Diagnostics, Tokyo, Japan) was used according to the manufacturer's instructions. Cat fibroblast cells with or without the inhibitor treatment were disaggregated using $0.25 \%$ trypsin-EDTA and suspended in DMEM supplemented with $20 \% \mathrm{FBS}$ and $50 \mu \mathrm{g} / \mathrm{mL}$ gentamicin in centrifuge tubes. Disaggregated cells were washed by centrifugation at $500 \times \mathrm{g}$ for $5 \mathrm{~min}$, resuspended in PBS, and then incubated in staining solution containing annexin V and PI for 10-15 min at room temperature. Stained cells (300 cells per sample) were examined under fluorescence microscopy at an excitation wavelength of $488 \mathrm{~nm}$. Cells emitting green light were considered apoptotic, while cells emitting green and red lights were considered necrotic. The percentage of apoptotic and necrotic cells was calculated by dividing the number of apoptotic and necrotic cells by the total number of counted cells, respectively.

\section{Oocyte preparation, SCNT and embryo culture}

Preparation of recipient oocytes and SCNT were conducted according to the method previously described (Kaedei et al., 2010). Briefly, bovine COCs were cultured in maturation medium consisting of TCM 199 with Earle's salts (Invitrogen) supplemented with $0.02 \mathrm{AU} / \mathrm{mL}$ of follicle stimulating hormone (FSH; Kawasaki Mitaka K. K., Kawasaki, Japan), 5\% FBS, and $50 \mu \mathrm{g} / \mathrm{mL}$ of gentamicin. Cat COCs were cultured in maturation medium consisting of TCM 199 with Earle's salts supplemented with $4 \mathrm{mg} / \mathrm{mL}$ of bovine serum albumin (BSA; SigmaAldrich), $0.1 \mathrm{IU} / \mathrm{mL}$ of human menopausal gonadotropin (TeikokuZoki, Tokyo, Japan), $10 \mathrm{IU} / \mathrm{mL}$ of human chorionic gonadotropin (hCG; TeikokuZoki), $1 \mu \mathrm{g} / \mathrm{mL}$ of $17 \beta$-oestradiol (Sigma-Aldrich), $10 \mathrm{ng} / \mathrm{mL}$ relaxin (Sigma-Aldrich) and $50 \mu \mathrm{g} / \mathrm{mL}$ of gentamicin. Bovine and cat COCs were respectively incubated for $22 \mathrm{~h}$ and $36 \mathrm{~h}$ in a drop of maturation medium $(10 \mathrm{COCs} / 100 \mu \mathrm{L})$ covered with mineral oil in a 
polystyrene culture dish at $38.5{ }^{\circ} \mathrm{C}$ in a humidified atmosphere containing $5 \%$ $\mathrm{CO}_{2}$. After maturation culture, the COCs were mechanically denuded in TCM199 medium supplemented with $0.1 \%$ (w/v) hyaluronidase (SigmaAldrich). Oocytes with the first polar body extrusion were collected and then incubated for $10 \mathrm{~min}$ in $3 \mu \mathrm{g} / \mathrm{mL}$ of Hoechst 33342 (Sigma-Aldrich) diluted in manipulation medium (PBS supplemented with $5 \%$ FBS and $5 \mu \mathrm{g} / \mathrm{mL}$ of cytochalasin B [Sigma-Aldrich]). The oocytes were then transferred to a drop of manipulation medium, and enucleated after minimal exposure to low-light filtered fluorescence. After each individual oocyte was enucleated, the donor cell was placed into the perivitelline space adjacent to the oocyte plasma membrane. Couplets were equilibrated for $3 \mathrm{~min}$ in Zimmerman cell fusion medium (Wolfe and Kraemer, 1992), transferred into a drop of Zimmerman cell fusion medium, and then manually aligned between two electrode needles connected to a micromanipulator (MO-202D; Narishige, Tokyo, Japan). Couplets with bovine and cat ooplasm were fused and activated with a single DC pulse of $2.3 \mathrm{kV} / \mathrm{cm}$ and $3.0 \mathrm{kV} / \mathrm{cm}$ for $30 \mu \mathrm{sec}$ by using an electro cell fusion generator (LF101; Nepagene, Chiba, Japan), respectively. The successfully fused couplets were activated in each culture medium supplemented with $10 \mu \mathrm{g} / \mathrm{mL}$ of cycloheximide (Sigma-Aldrich) and incubated for $5 \mathrm{~h}$. Following cycloheximide treatment, the couplets were cultured in a modified synthetic oviduct fluid (mSOF) medium (Kwun et al., 2003) supplemented with $4 \mathrm{mg} / \mathrm{mL}$ bovine serum albumin (BSA; Sigma-Aldrich) and $50 \mu \mathrm{g} / \mathrm{mL}$ of gentamicin for $72 \mathrm{~h}$ at $38.5{ }^{\circ} \mathrm{C}$ in a humidified atmosphere of $5 \% \mathrm{CO}_{2}$ and $5 \%$ $\mathrm{O}_{2}$. After $72 \mathrm{~h}$ of culture, only cleaved embryos were further co-cultured with cumulus cells in mSOF supplemented with $5 \% \mathrm{FBS}$ at $38.5^{\circ} \mathrm{C}$ in a humidified $5 \% \mathrm{CO}_{2}$ atmosphere for an additional 5 days to evaluate their ability to develop to the blastocyst stage.

\section{Statistical analysis}

The experiments were repeated 4-8 times for each treatment. The percentages of cells reaching each cell-cycle stage, fused embryos, cleaved embryos, and embryos developed to the blastocyst stage were subjected to arcsine transformation before analysis of variance (ANOVA). The transformed data were tested by ANOVA followed by Fisher's protected least significant difference (PLSD) test using the StatView program (Abacus Concepts, Inc., Berkeley, CA, USA). Differences with a probability value of $\mathrm{P} \leq 0.05$ were considered statistically significant.

\section{Results}

The percentage of cells arrested at the $\mathrm{G} 0 / \mathrm{G} 1$ phase in the roscovitine treatment group was similar to that in the control group $(76.5 \%$ vs. $74.4 \%, \mathrm{P}>$ 0.05) (Fig. 1). Similarly, the percentages of cells arrested at the S and G2/M 
phases did not differ between the two groups. In the demecolcine group, the percentage of cells arrested at the G2/M phase was significantly higher and that of cells arrested at the G0/G1 phase was lower than in the control group (32.5\% vs. $10.8 \%$ and $48.5 \%$ vs. $74.4 \%$, respectively; $\mathrm{P}<0.05$ ).

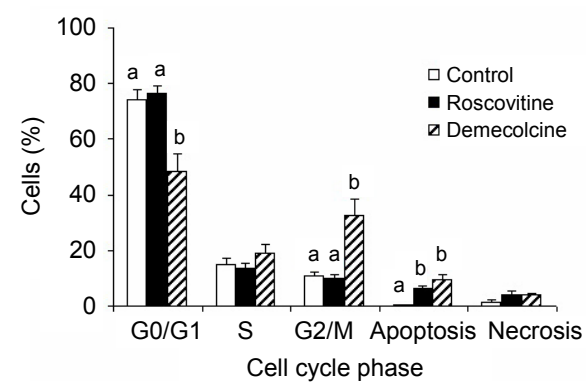

Fig. 1. Cell cycle and viability of domestic cat fibroblast cells treated with chemical inhibitors. Somatic cells from the domestic cat ovary were cultured in DMEM supplemented with $10 \%$ fetal bovine serum and $15 \mu \mathrm{g} / \mathrm{mL}$ roscovitine or $0.05 \mu \mathrm{g} / \mathrm{mL}$ demecolcine for $24 \mathrm{~h}$. Bars with different letters differ significantly $(\mathrm{P}<0.05)$

The percentages of apoptotic cells in both the roscovitine and demecolcine groups were significantly higher than those in the control group $(6.5 \%$ and $9.5 \%$ vs. $0.4 \%$, respectively; $\mathrm{P}<0.05$ ). However, there were no differences in the percentages of necrotic cells among the groups.

The percentage of fusion of the couplets was significantly higher $(\mathrm{P}<$ 0.05 ) in the roscovitine group than in the non-treated control group (Table 1). Moreover, the percentage of fusion in the roscovitine group was similar to that in the demecolcine and homogeneous control groups (bovine and cat NT groups). There were no differences in the percentages of total cleavage (the $\geq 2$-cell stage) and development to the $\geq 8$-cell stage among the iSCNT groups. None of the iSCNT embryos developed to the morula or blastocyst stage. A significantly higher number of intraspecies embryos in the bovine and cat NT groups cleaved and developed to the blastocyst stage as compared to that in the iSCNT groups $(\mathrm{P}<0.05)$.

\section{Discussion}

The first cloned sheep Dolly was successfully produced by transferring an adult somatic cell at the resting or G0 phase that was synchronised by serum starvation for 4-5 days into an enucleated oocyte (Wilmut et al., 1997). In previous studies, donor cells at the G2/M phase could also be reprogrammed by the MII oocytes, and the reconstructed embryos were able to develop to the blastocyst stage (Korfiatis et al., 2001; Zhou et al., 2001). In the present study, we examined the effect of different inhibitors on the cell-cycle synchronisation of fi- 
broblast cells from the cat ovary and the development of iSCNT embryos after reconstruction. Flow cytometry showed that roscovitine treatment could not increase the proportion of cells arrested at the G0/G1 phase in comparison with the control group. These results are in agreement with those of Hinrichs et al. (2006) who reported that roscovitine treatment did not significantly affect the proportion of horse cells in the G0/G1 phase. In contrast, Gómez et al. (2003) showed that fibroblast cells from skin tissues of the domestic cat could be synchronised to the G0/G1 phase by roscovitine treatment as compared to cycling cells. In our previous study, we found that the effects of roscovitine treatment on the rates of G0/G1 phase differed among the felid species (Wittayarat et al., 2013). One possible explanation for the different effects of roscovitine on cell-cycle synchronisation is that it may result from different cell origins. Moreover, our findings indicate that cell treatment with $15 \mu \mathrm{g} / \mathrm{mL}$ roscovitine might not be optimal for cell-cycle synchronisation in fibroblast cells derived from the cat ovary.

On the other hand, we successfully synchronised the domestic cat cells to the $\mathrm{G} 2 / \mathrm{M}$ phase using $0.05 \mu \mathrm{g} / \mathrm{mL}$ demecolcine treatment. Our results are in agreement with those of the experiment of $\mathrm{Li}$ et al. (2005a) who reported that $0.05 \mu \mathrm{g} / \mathrm{mL}$ demecolcine treatment effectively synchronised ferret fibroblast cells in the M-phase of the cell cycle and that a cloned ferret fetus could be produced from M-phase fibroblasts. However, we found that cell treatment with roscovitine or demecolcine induced higher rates of apoptosis in treated cells. It has been suggested that the addition of apoptosis inhibitors such as antioxidants can reduce DNA fragmentation in treated cells without affecting cell-cycle synchronisation (Lee and Piedrahita, 2002). Therefore, further experiments concerning the effect of apoptosis inhibitors are required to find the optimal condition for cell-cycle synchronisation in cat fibroblast cells.

Gómez et al. (2003) reported that the method used for cell-cycle synchronisation, such as roscovitine treatment, serum starvation and contact inhibition, did not affect the fusion and cleavage rate of the couplets reconstructed from domestic cat oocytes and African wild cat donor cells. Factors affecting the fusion efficiency in nuclear transfer include the cell cycle phase of donor cell, the donor cell type and the age of the recipient oocyte ( $\mathrm{Li}$ et al., 2005b). Cheong et al. (1993) demonstrated that a significantly higher fusion rate was obtained in the mouse couplets reconstructed from the donor cell in $\mathrm{G} 2 / \mathrm{M}$ phase than in the $\mathrm{G} 0 / \mathrm{G} 1$ phase. In the present study, there was no significant difference in the fusion rates between the roscovitine and demecolcine treatment groups, but the percentage of cells arrested at the G2/M phase was significantly higher in the demecolcine treatment group than in the roscovitine treatment group. In contrast, a higher fusion rate of couplets reconstructed with bovine enucleated oocytes was observed in the roscovitine treatment group than in the control group, although the proportions of cells arrested at the G0/G1 and G2/M phases did not differ between the two groups. Our results indicate that the fusion efficiency in iSCNT embryos might not depend on the cell cycle phase of donor cells. 


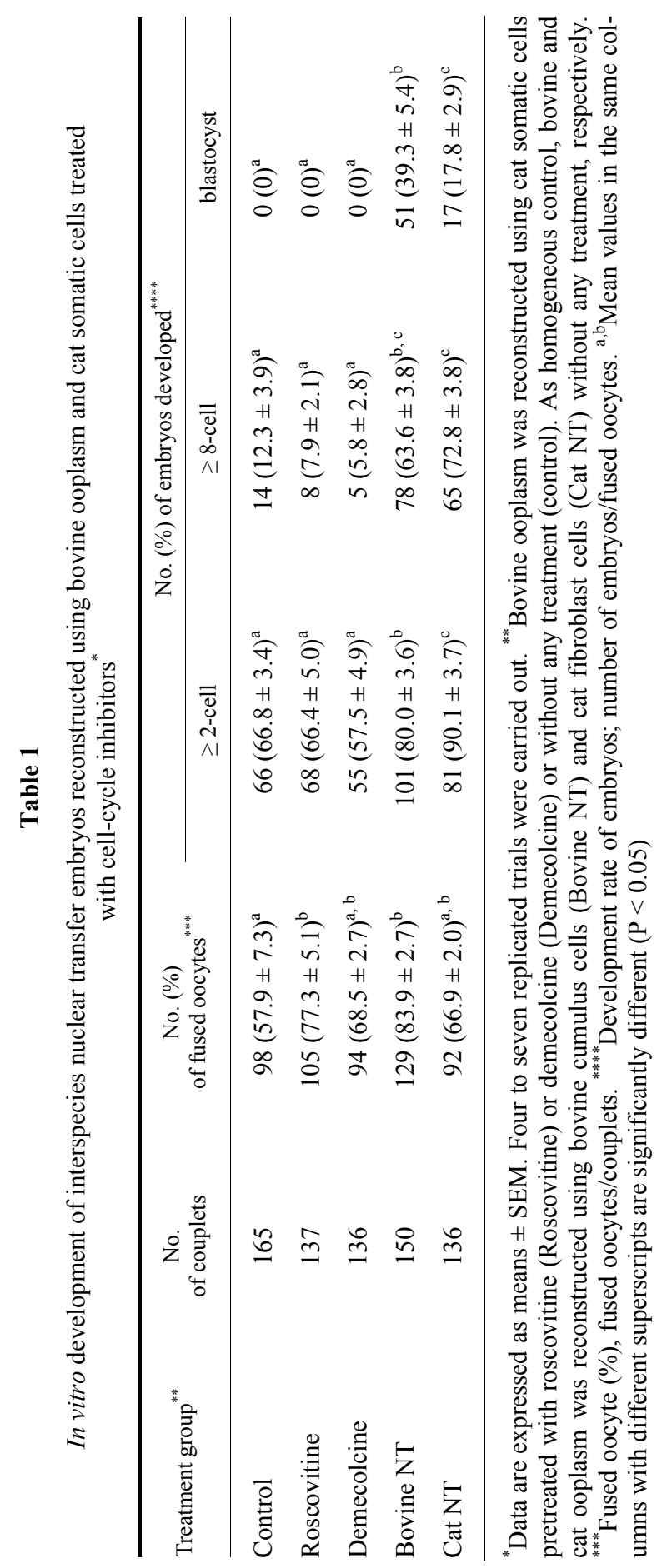


The early stages of embryogenesis are controlled by maternally inherited products stored in the ooplasm. There are species-specific differences in the developmental period of transition from maternal to embryonic control. In the domestic cat, the timing of the switch from maternal to embryonic genome control occurs by the 5- to 8-cell stage (Hoffert et al., 1997). It has been suggested that rabbit oocytes support the development to the blastocyst stage of cat-rabbit iSCNT embryos (Thongphakdee et al., 2006). In our previous report, we demonstrated that cat cells can also be reprogrammed in bovine and porcine cytoplasm; however, the cat-cow and cat-pig iSCNT embryos could not develop to the late embryonic stage (Kaedei et al., 2010). In the present study, similarly, none of the cat-cow iSCNT embryos with cell-cycle synchronisation of donor cells could develop to the morula or blastocyst stage, although the intraspecies cloned embryos in the homogeneous control groups (bovine and cat NT groups) developed to the blastocyst stage. Thongphakdee et al. (2008) reported that the genotype of mitochondrial DNA (mtDNA) in the cat-cow iSCNT embryos has shown heteroplasmy with a reduction in the copy number of mtDNA. Therefore, the developmental block of iSCNT embryos might be related to the lack of transition from the maternal to embryonic control or mitochondrial incompatibility between the recipient oocytes and donor cells. These results indicate that induction of cellcycle synchronisation of donor cells by chemical inhibitors cannot overcome the developmental arrest of iSCNT embryos, which may be affected by the incomplete transition of the maternal zygote or by mitochondrial heteroplasmy.

In conclusion, $15 \mu \mathrm{g} / \mathrm{mL}$ roscovitine treatment did not create appropriate conditions for synchronising domestic cat fibroblast cells to the G0/G1 phase, whereas $0.05 \mu \mathrm{g} / \mathrm{mL}$ demecolcine treatment increased the proportions of cells arrested at the G2/M phase. However, cell-cycle synchronisation treatment of donor cells by the chemical inhibitors had no effect on the development of the iSCNT embryos. These results indicate that cell-cycle synchronisation of donor cells does not overcome the developmental arrest of iSCNT embryos.

\section{Acknowledgements}

The authors thank the staff of the Meat Inspection Office of Kitakyushu city, Japan, for supplying bovine ovaries. This study was supported in part by a grant from the Ministry of Education, Science and Culture of Japan.

\section{References}

Beyhan, Z., Iager, A. E. and Cibelli, J. B. (2007): Interspecies nuclear transfer: implications for embryonic stem cell biology. Cell Stem Cell 1, 502-512. 
Campbell, K. H., Loi, P., Otaegui, P. J. and Wilmut, I. (1996): Cell cycle co-ordination in embryo cloning by nuclear transfer. Rev. Reprod. 1, 40-46.

Chen, D. Y., Wen, D. C., Zhang, Y. P., Sun, Q. Y., Han, Z. M., Liu, Z. H., Shi, P., Li, J. S., Xiangyu, J. G., Lian, L., Kou, Z. H., Wu, Y. Q., Chen, Y. C., Wang, P. Y. and Zhang, H. M. (2002): Interspecies implantation and mitochondria fate of panda-rabbit cloned embryos. Biol. Reprod. 67, 637-642.

Cheong, H. T., Takahashi, Y. and Kanagawa, H. (1993): Birth of mice after transplantation of early cell-cycle-stage embryonic nuclei into enucleated oocytes. Biol. Reprod. 48, 958-963.

Dominko, T., Mitalipova, M., Haley, B., Beyhan, Z., Memili, E., McKusick, B. and First, N. L. (1999): Bovine oocyte cytoplasm supports development of embryos produced by nuclear transfer of somatic cell nuclei from various mammalian species. Biol. Reprod. 60, 1496-1502.

Gibbons, J., Arat, S., Rzucidlo, J., Miyoshi, K., Waltenburg, R., Respess, D., Venable, A. and Stice, S. (2002): Enhanced survivability of cloned calves derived from roscovitine-treated adult somatic cells. Biol. Reprod. 66, 895-900.

Gómez, M. C., Jenkins, J. A., Giraldo, A., Harris, R. F., King, A., Dresser, B. L. and Pope, C. E. (2003): Nuclear transfer of synchronized African wild cat somatic cells into enucleated domestic cat oocytes. Biol. Reprod. 69, 1032-1041.

Hinrichs, K., Choi, Y. H., Love, C. C., Chung, Y. G. and Varner, D. D. (2006): Production of horse foals via direct injection of roscovitine-treated donor cells and activation by injection of sperm extract. Reproduction 131, 1063-1072.

Hoffert, K. A., Anderson, G. B., Wildt, D. E. and Roth, T. L. (1997): Transition from maternal to embryonic control of development in IVM/IVF domestic cat embryos. Mol. Reprod. Dev. 48, 208-215.

Jiang, Y., Chen, T., Nan, C. L., Ouyang, Y. C., Sun, Q. Y. and Chen, D. Y. (2005): In vitro culture and mtDNA fate of ibex-rabbit nuclear transfer embryos. Zygote 13, 233-240.

Kaedei, Y., Fujiwara, A., Tanihara, F., Namula, Z., Viet, V. and Otoi, T. (2010): In vitro development of cat interspecies nuclear transfer using pig's and cow's cytoplasm. B. Vet. I. Pulawy 54, 405-408.

Karja, N. W., Otoi, T., Wongsrikeao, P., Shimizu, R., Murakami, M., Agung, B., Fahrudin, M. and Nagai, T. (2006): Effects of electric field strengths on fusion and in vitro development of domestic cat embryos derived by somatic cell nuclear transfer. Theriogenology 66, 1237-1242.

Korfiatis, N., Trounson, A. and Lacham-Kaplan, O. (2001): Cell synchronization for the purposes of nuclear transfer in the bovine. Cloning Stem Cells 3, 125-138.

Kwun, J., Chang, K., Lim, J., Lee, E., Lee, B., Kang, S. and Hwang, W. (2003): Effects of exogenous hexoses on bovine in vitro fertilized and cloned embryo development: Improved blastocyst formation after glucose replacement with fructose in a serum-free culture medium. Mol. Reprod. Dev. 65, 167-174.

Lee, C. K. and Piedrahita, J. A. (2002): Inhibition of apoptosis in serum starved porcine embryonic fibroblasts. Mol. Reprod. Dev. 62, 106-112.

Li, Z., Chen, X., Sun, X., Zhou, Q., Chen, J., Leno, G. H. and Engelhardt, J. F. (2005a): Nuclear transfer of M-phase ferret fibroblasts synchronized with the microtubule inhibitor demecolcine. J. Exp. Zool. A Comp. Exp. Biol. 303, 1126-1134.

Li, Z., Sun, X., Chen, J., Leno, G. H. and Engelhardt, J. F. (2005b): Factors affecting the electrofusion of mouse and ferret oocytes with ferret somatic cells. Mol. Reprod. Dev. 72, 40-47.

Murakami, M., Otoi, T., Wongsrikeao, P., Agung, B., Sambuu, R. and Suzuki, T. (2005): Development of interspecies cloned embryos in yak and dog. Cloning Stem Cells 7, 77-81.

Thongphakdee, A., Kobayashi, S., Imai, K., Inaba, Y., Tasai, M., Tagami, T., Nirasawa, K., Nagai, T., Saito, N., Techakumphu, M. and Takeda, K. (2008): Interspecies nuclear transfer embryos reconstructed from cat somatic cells and bovine ooplasm. J. Reprod. Dev. 54, 142-147.

Thongphakdee, A., Numchaisrika, P., Omsongkram, S., Chatdarong, K., Kamolnorranath, S., Dumnui, S. and Techakumphu, M. (2006): In vitro development of marbled cat embryos derived from interspecies somatic cell nuclear transfer. Reprod. Domest. Anim. 41, 219-226. 
White, K. L., Bunch, T. D., Mitalipov, S. and Reed, W. A. (1999): Establishment of pregnancy after the transfer of nuclear transfer embryos produce from the fusion of argali (Ovis ammon) nuclei into domestic sheep (Ovis aries) enucleated oocytes. Cloning 1, 47-54.

Wilmut, I., Schnieke, A. E., McWhir, J., Kind, A. J. and Campbell, K. H. (1997): Viable offspring derived from fetal and adult mammalian cells. Nature 385, 810-813.

Wittayarat, M., Thongphakdee, A., Saikhun, K., Chatdarong, K., Otoi, T. and Techakumphu, M. (2013): Cell cycle synchronization of skin fibroblast cells in four species of family Felidae. Reprod. Domest. Anim. 48, 305-310.

Wolfe, B. A. and Kraemer, D. C. (1992): Methods in bovine nuclear transfer. Theriogenology 37, $5-15$.

Zhou, Q., Jouneau, A., Brochard, V., Adenot, P. and Renard, J. P. (2001): Developmental potential of mouse embryos reconstructed from metaphase embryonic stem cell nuclei. Biol. Reprod. 65, 412-419. 